\title{
Franchise Relationship: Free-Riding Emergence of Local Indonesian Franchised F\&B Brands
}

\author{
Ebenezer Nickson Neequaye ${ }^{1}$, Huang Dechun ${ }^{1,}$, , Rosemary Boateng Coffie ${ }^{2}$, \\ Puput Ichwatus Sholihah $^{3}$, Nelson Amowine ${ }^{1}$, Stella Fynn ${ }^{1}$, Rita Karley Richardson ${ }^{1}$ \\ ${ }^{1}$ Department of Industrial Economics, Hohai Business School, Hohai University, Nanjing, China \\ ${ }^{2}$ Department of Human Resource and Organizational Development, Kwame Nkrumah University of Science and Technology, Kumasi, \\ Ghana \\ ${ }^{3}$ Department of Engineering and Project Management, Public Administration School, Hohai University, Nanjing, China
}

\section{Email address:}

huangdechun@hhu.edu.cn (H. Dechun)

*Corresponding author

\section{To cite this article:}

Ebenezer Nickson Neequaye, Huang Dechun, Rosemary Boateng Coffie, Puput Ichwatus Sholihah, Nelson Amowine, Stella Fynn, Rita Karley Richardson. Franchise Relationship: Free-Riding Emergence of Local Indonesian Franchised F\&B Brands. American Journal of Management Science and Engineering. Vol. 2, No. 6, 2017, pp. 183-191. doi: 10.11648/j.ajmse.20170206.14

Received: September 25, 2017; Accepted: November 10, 2017; Published: December 18, 2017

\begin{abstract}
This study aims to analyze the relationship in the franchise business local Indonesian F\&B brands. Samples are taken of 500 respondents; in 5 major cities of the local F\&B brands franchise business in Indonesia. This study is using convenience sampling. SEM (Structural Equations Model) analysis technique in this research was used by making use of existing software AMOS (Analysis of Moment structure) version 18.00. The findings suggest that centralization has no significant effect on free riding behavior. The study states that the behavior of free riding can not be discounted by formalization, however, the result also demonstrate interaction may prevent free riding behavior. The result indicates that competition (external competition) can also reduce the possibility of free riding behavior in local Indonesia F\&B Franchise.
\end{abstract}

Keywords: Franchise, Free Riding, F\&B Franchise, Indonesia

\section{Introduction}

A country is said to be successful in economy if most of the population has a quality of entrepreneur. Countries that want to advance the economy, at least require $2 \%$ of its population to become an entrepreneur. Only a society with a formidable entrepreneur level will arise a strong economy as well. Entrepreneurs, in start-up stage, at first encountered many obstacles, due to not obtaining financial support or management. In this reform era, Indonesia began to face the global challenges in business, inter alia by authorizing the Antimonopoly Law, so anyone can plunge into the business world. In business, it is not easy to achieve success, many challenges to be faced. Many fall in the early stages of a business establishment, therefore many entrepreneur beginners are hesitant to start business [1].

In such a situation, emerge the concept of business cooperation can reduce the risk of doing business, one of the business concept is franchise. Franchise is the grant of a license by a (franchisor) to another party (franchisee), the license entitles the franchisee to try using the trademark / trade name of the franchisor, and use the whole package, which consists of all the elements needed to make people who previously have not been trained to run it with the help of continuous on the grounds that had been predetermined [2].

Franchising affords significant benefits, but also bring considerable cost and risk compared to other methods of distribution [3]. The advantage of a franchisee's perspective is the ability to overcome the lack of basic knowledge and specially, the franchisee gets an extra incentive help continuously from franchisor, operating under the brand that has been established, require smaller capital than independent business, advertising and promotional activities benefit from the franchisor, the risk business is reduced, benefit from the use of patents, trademarks, copyrights, trade secrets, 
processes, formulas, access to sources of loan easier. Also Franchising has several distinctive disadvantages. Weaknesses from the perspective of a franchisee is suppression control, the fee to the franchisor, franchisor quality difficulties, restrictions, too dependent, policy mistakes of the franchisor.

In Indonesia, Business franchise grew rapidly before the crisis, but at times of crisis in 1998 these businesses tend to stagnate [4]. The franchise returned to growth in $2000 \mathrm{~s}$, it was marked by the proliferation of franchise businesses both foreign and local. In the last 10 years, in Indonesia has many local emerging franchise business. Chairman of the Indonesian Franchise and Lisesi, an average growth of the local franchise business in Indonesia reach the number of 8$9 \%$ each year [5]. In the long run these local franchise business prospects remain bright, because they have many advantages system that are not owned by the conventional business. Franchising has proven as a successful business, as it has been achieved by many Indonesian local F\&B franchise that has been successfully developing its business, as J. Co Donuts and Coffee, Ayam Bakar Wong Solo, Es Teler 77, Bumbu Desa, and Kebab Turki Baba Rafi. In Indonesia, there are approximately 698 franchises by the number of outlets as many as 23.844 units consisting of $63 \%$ of local franchises and $37 \%$ of foreign franchises (Intra magazine, 2015). In the context of the broad economy using a franchise establishment can promote the growth and development of medium and small entrepreneurs who could further enhance economic growth.

Franchise business in Indonesia are mostly engaged in the industry food and beverage (F\&B). Based on a survey conducted by Majalah Info Franchise (Info Franchise Magazine) in cooperation with Dinamic (Ide Bisnis, 2011), total value of the Indonesian Franchise business in 2010 amounted to Rp 114, 56 trillion, Rp 42.6 trillion held by F\&B business. This amount is very large, because the number is more than half the total value of the franchise business in 2008 which amounted to $\mathrm{Rp} 81.14$ trillion. Pietra Sarosa in Ide Bisnis (2011) states that F\&B franchise is still a trend, because the culinary business is considered by the principal and partner, easy operation and a broad market. Its capital is not too big, but if it is successful, the turnover obtained can be more than 2-fold. However, from 1,500 franchisees and business opportunity, it was revealed $60 \%$ of the local franchise went bankrupt or failed to apply the concept of franchise [6]. Most of the failures are local F\&B franchise brand. There are several causes; first, the franchisor has his intention to sell their products only. Franchise business management is sometimes overlooked, the second cause is the lack of experience. Many franchise, which recently established new and has one branch already sell the business to be franchise, thus failing in the market.

Another problem that can lead to business failure is an antagonistic relationship often occurs between the franchisor and franchisee. The franchisor has the right to monitor and evaluate the behavior of franchisees as written in the contract. On the other side franchisee wants to have the freedom to manage their businesses because they feel they own capital. In this condition, a lot of literature mentions the possibility franchisee to practice free riding behavior. Free riding can be defined as a practice that causes losses to franchisees that do not actually want to cut the cost or quality of the goods sold [7]. Free riding practice is very detrimental to the trademark and this is a serious problem for franchisees [8] [9].

According to Kidwell et al. (2007) factors that lead to free riding in the franchisor-franchisee relationship are centralization, formalization, interaction, and external competition. Centralization refers to the extent to which the authority to take decisions concentrated. The greater centralization focused on the franchisor management (centralized management), the easier it conflict between the franchisor-franchisee can be controlled and limit free riding. On the other side, formalization is defined as the rules and procedures specified in the franchisor-franchisee relationship, to minimize expectations and misunderstandings [9]. In the franchisor-franchisee relationship, communication concepts and interactions of both parties are expected to exist in activities, resources, and information. While external competition here can be addressed for both interbrand and intrabrand competition. This kind of competition is believed would make franchisee increase effort to avoid negative consequences (free riding).

A free riding franchise can cause problems for the franchisor because the customer will add the brand to the quality of the goods / service for the whole chain [10]. This condition raises, because individual franchisees generate onetime sales, but the entire system on the franchise chain loses customers. If done freely up a lot done, then the entire chain system because of this action damage the image and reputation of the brand. (Brickley and Dark 1987; Michael 2000). If a franchisee withhold effort and successfully free rides on the franchisor's brand name, this may reflect poorly on perceived brand quality and lead to poor organizational performance [9]. The ability to control free riding behavior is crucial for productivity and survival of business [11]. Mainly during last decade there are large number of empirical studies about this issue [8], [9], [11], [12]. This study addresses the problem of free riding behavior as franchisee-franchisor relationship in F\&B local franchise in Indonesia. The phenomenon of free riding by finding the factors that can affect this behavior.

\section{Literature Review and Hypothesis Development}

\subsection{Franchising in Indonesia}

At first, the term franchise unknown in Indonesian legal literature. This is understandable because the franchise since the beginning are not in the business culture or tradition of Indonesian society. However, due to the influence of globalization that swept in various fields, the franchise then into the cultural order and the legal order of Indonesian 
society. The term franchise went on to become a familiar term with the community, especially the Indonesian business community and drew attention to the depths. Then the term franchise replaced with the term franchise was first introduced by Lembaga Pendidikan dan Pengembangan Manajemen (LPPM). Franchising is derived from the word wara, which means more or privileged and laba means profit. Thus, waralaba (franchise) means businesses that provide advantages over / special [13].

According to Article 1 Paragraph (1) PP 42 Year 2007 on Franchise declared Franchise is special right owned by an individual or business entity to a business system with distinctive feature in order to market their goods and/or services that have proved successful and can be utilized and/or used by other parties under the franchise agreement. According to Article 1 Paragraph (1) of the Regulation of the Minister of Trade No. 31 / M-DAG / PER / 8/2008 on the Implementation of Franchises (hereinafter referred to as Regulation 31 of 2008) states that, the franchise that special rights owned by an individual or business entity to the system business with distinctive feature in order to market their goods and/or services that have proven successful and can be used and / or used by other parties under the franchise agreement.

Indonesian Franchise Association itself gives a different meaning of the franchise, is the franchise is a system of distribution of goods or services to the end customer, where the brand owner (franchisor) gives rights to individuals or companies to conduct business under the brand name, systems, procedures and ways that are predefined within a certain period covers a certain area [14].

\subsection{Free Riding}

According to Caves and Murphy (1976) free riding is defined as the circumstance in which at the same price, franchisee reduces the quality of the goods / services, this condition is usually intended to increase personal profit. Nevertheless it is clear that the free riding practice will disappoint customers. Free riding practices are done if ftranchisee because they do not think to create customer loyalty in business [15].

According to Dant and Gundlach (1999) free riding is an event (inherent / inevitable) when a franchisee trying to be more autonomous in its business and the franchisor when trying to apply the standards to their business operations. In this study, we refer free riding as a situation where the franchisee enjoys the benefit of membership in the franchisor (collaborative venture), without bearing the full costs and constrains related to it [11].

\subsection{Theoretical Perspective and Hypotheses}

In formulating hypotheses, we replicate the research that has been done by Kidwell et, al. (2007) where in the study composed of three kinds of elements of the motivation model to increase commitment and limit free-riding by considering the structural variables (centralization, formalization, interaction) as considering the variables that consider franchisor-franchise relations (external competition). The study only focuse on the factors that can encourage Local F\&B franchisees carry out free riding behavior. Relationships proposed in this study are shown in figure 1.

\subsubsection{Centralization}

Centralization is the hierarchy that are applicable to decision-making. If decisions are at the top level and centered it is centralized [16]. In franchising activities, centralization creates a non-participatory environment which will reduce communication, commitment, and task involvement among participants [17]. Franchisee usually invests not with the purpose to be regulated by the central rules. If it is overcontrolled, the franchisee becomes lack of trust, this situation may trigger undesirable action, and the possibility of free-riding is increasing [9].

H1. The level of centralization in a franchise relationship is positively related to free riding behavior

\subsubsection{Formalization}

Formalization measures the extent to which organization uses rules and procedures to decribe behavior [18]. Formalization indicates the extent to which the rights, duties, and obligations of members of the organization are described and the extent to which these matters are written down in rules, procedures and intructions [19]. Formalization formulated in this study is the degree to which the franchisees are provided with rules and procedures that may encourage or even hunder creativity, autonomus work and learning. In franchisee-franchisor relationship with high degree of formalization, there are explicit rules that tend to impede the spontaneity and flexibility required for business innovation [17], [20]. Formalization are inversely relared to free riding behavior. Formalization makes franchisees avoid free riding behaviors in running the business due to the formal relationship and rules, each party know the rights and obligations of each.

$\mathrm{H} 2$. The level of formalization in franchise relationship is negatively related to free riding behavior.

\subsubsection{Interaction}

In relation to the relationship between franchisor and franchisee, the concept of interaction is described as a flow of activities, resources, and information from franchisor to the franchisees and the communication that occurs between the two [21]. Interaction between the franchisor and franchisee is an important activity for the relations between the two sides. Franchisee who interact regularly with franchisor can increase level of monitoring by franchisor. Such conditions are expected to minimize the possibility of free riding behavior [9]. Good interaction will be inversely proportional to free riding. Intensive interaction between the two sides will minimize bias in business information and minimize the possibility of free riding behavior.

H3. The level of interaction between franchisor and franchisee is negatively related to free riding.

While the high external competition makes franchisee 
more stricly maintaining quality standards or in other words could minimize the occurrence of free riding behavior [9]. These conditions happen because the franchisees are well aware of the existence of another competitor in a business that must be wary of their motions in order not to endanger the business.
H4. The degree of external competition faced by franchisee is negatively related to free riding.

Based on the hypothesis formulation and review of the literature on top then developed a research model depicted in the chart below:

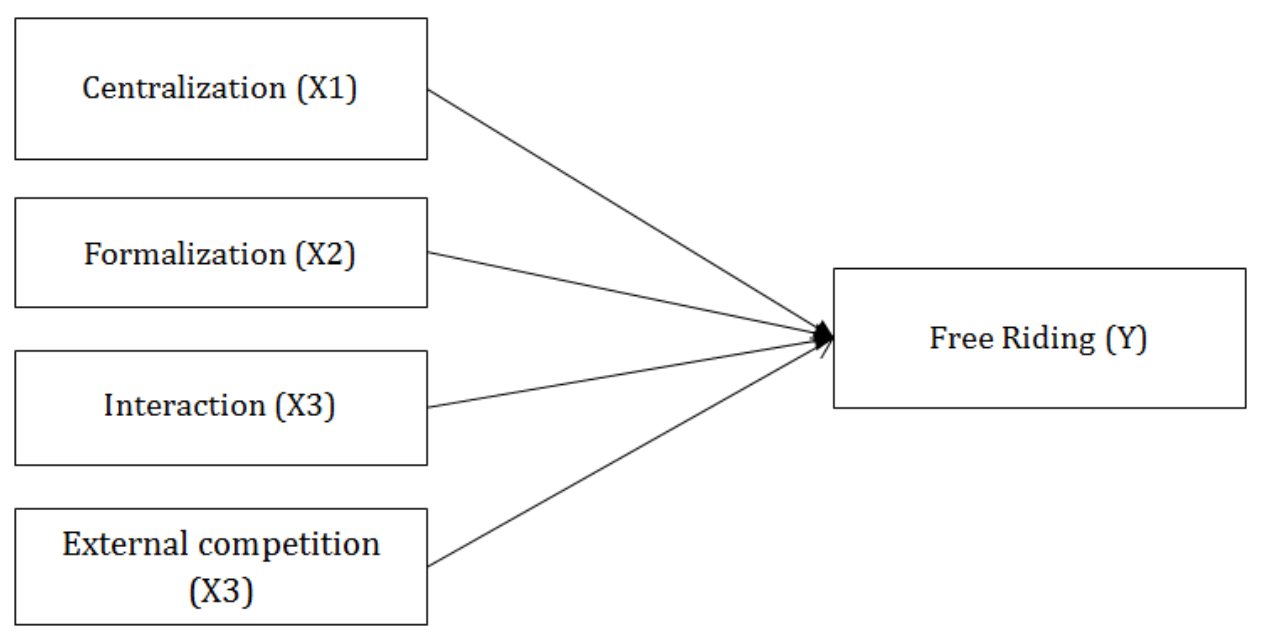

Figure 1. Conceptual Framework.

\section{Research Methods}

This research is a explanative research as it aims to examine the characteristics of variables and relationships between variables that already exist. The study also aimed to explain the cause and effect relationships. From the investigation, this study analyzes the causality causal relationship between variables.

\subsection{Population and Sampling Techniques}

The study population was limited to the scope of the local F\&B brands franchise business in Indonesia who are in 5 major cities: Jakarta, Bandung, Yogyakarta, Surabaya, and Malang. 5 The city chosen by consideration of the number of local franchise businesses in the five cities and also considered to represent the phenomenon of the franchise in Indonesia. The data used in this study are primary data. Primary data obtained from interviews regarding the respondents. The method used for data collection is by interview on selected respondents using a questionnaire tools (questionnaires). This research was conducted by using convenience sampling technique, where the research subject was chosen because it is convenient accessibility and close to the researcher. Samples are taken of 500 respondents; each of the 100 respondents for each city.

The relationship between franchisee and franchisor's managers dealers used to develop theoritical construcs and measurements in this study. In this study collected information from both sides, the questionnaire that was adapted to the respective role (whether the franchisor or franchisee) was given to both parties. Sample in this research is just the franchise local F\&B which is considered to have a structured franchise system. The list of local F\&B franchises that have been presented in the following table.

Table 1. Local F\&B Franchise List.

\begin{tabular}{ll}
\hline J. Co Donuts and Coffe & Bebek Slamet \\
Papa Ron's Pizza & RotiBoy \\
Ayam Bakar Wong Solo & Andrew Crepes \\
Es Teler 77 & Ayam Goreng Fatmawati \\
Bumbu Desa & Sederhana Restoran Masakan Padang \\
Kebab Turki Baba Rafi & Solaria \\
Quick Chicken & Sop Duren Lodaya \\
Bakso Kota Cak Man & Coffe Toffe \\
\hline
\end{tabular}

Furthermore, we hold the sample selection. Of 16 local F\&B franchise brands, we conducted the questionnaire addressed to the franchisor to franchisor represent. From the franchisor who has answered our questions, franchisor asked to show some franchisee which in their supervision, each franchisor show the specific franchisees from one to seven. From the franchisor's information we conduct interviews for the franchisee. The amount of data we receive is different from every city. From Jakarta we received 72 of which 9 questionnaires from the franchisor and 63 questionnaires from the franchisee. From Bandung we received a total of 107 questionnaires, of which 13 questionnaires from 94 of the franchisor and the franchisee. From Yogyakarta we received 94 questionnaires with sdetails 9 questionnaire from the franchisor and 85 questionnaires from the franchisee. While from Surabaya we received 83 questionnaires in which 11 of 72 from the franchisor and the franchisee. From Malang we received 144 questionnaires with details of 15 of the 129 questionnaires from the franchisor and the franchisee. In total we received 57 questionnaires from the franchisor and 443 questionnaires from the franchisee. 


\subsection{Measures}

Research questions in the questionnaire is to find information related in franchisee-franchisor relationship in free riding issue by using variables: centralization, formalization, interaction, external competition and free riding. Every variables meansured by five point likert scale. All items in this study were adopted from Kidwell et. al. (2007). Centralization items asked the extent to which conditions the franchisor influence franchisee's decisions of factors such as opening hours at the station, station design, purchasing terms, loan warrant, and employees' salaries. Formalization measured procedures or rules of solving problems that have been formulated in the agreements, such as how to run sales, and how to design the station's shops. Interaction items reflected the frequency of communication, interaction and cooperation between two sides in business activities such as contact levels, marketing planning, business objectives formulation, advertising, finance, macroeconomic analysis, accounting, and human resource management. External competition item asked the extent to which the explanation level of competition for their market share, regardless of brand. Free riding items captured the degree of the urgency of controlling such as the store service, the rules to keep the store clean (in the least and many customers), the things mentioned above should be discussed further and in detail between the franchisee and the franchisor.

\section{Result Data Analysis}

\subsection{Goodness of Fit Test}

The model is said to be good if it meets the criteria of goodness of fit. Goodness of fit describes the suitability test and statistical tests. In this study initially showed that the results of goodness of fit does not meet the criteria specified critical value. This means that of all the criteria used showed poor results as well, which means that the model does not fit the data, so the model is not fit for use. It is generally very rare to find a model that will fit on the initial model. Sometimes modification models are needed to better model fitting. AMOS application provides clues to the model by using a modification index to generate additional models according to chi-square for each path that may be added to the model. However, modification of the model should still be based on the particular theory, not just based on the numbers contained in the modification indices. In this research, modifications done by connecting the variable inquiring about the formal relationship between franchisor and franchisee with variables that inquire of good interaction between frachisor and franchisee. Other than by the number shown on the modification indices, by linking these variables is assumed that the interaction between the franchisor and franchisee is a formal interactions, so they can be connected to each other.

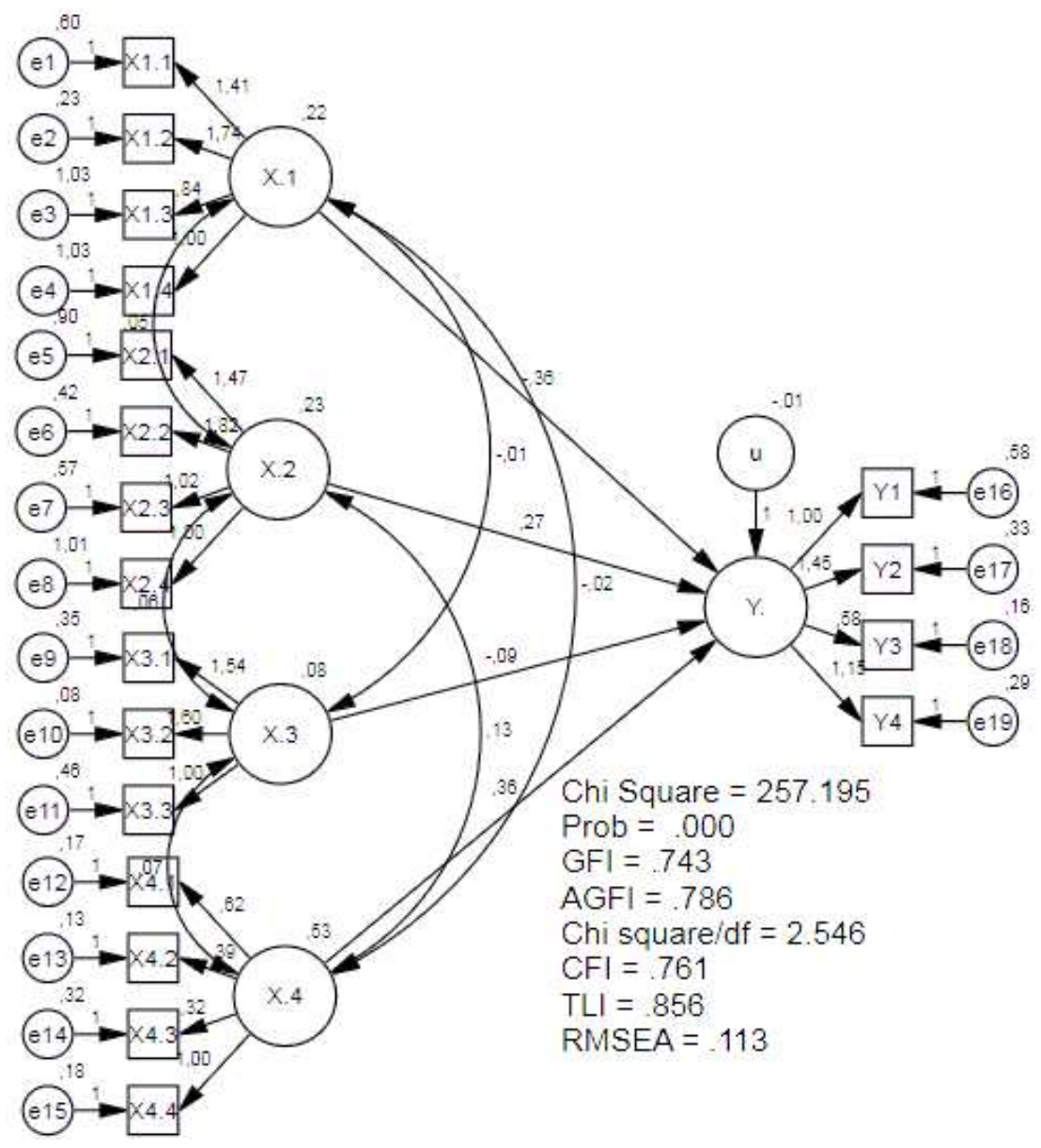

Figure 2. Initial Model. 


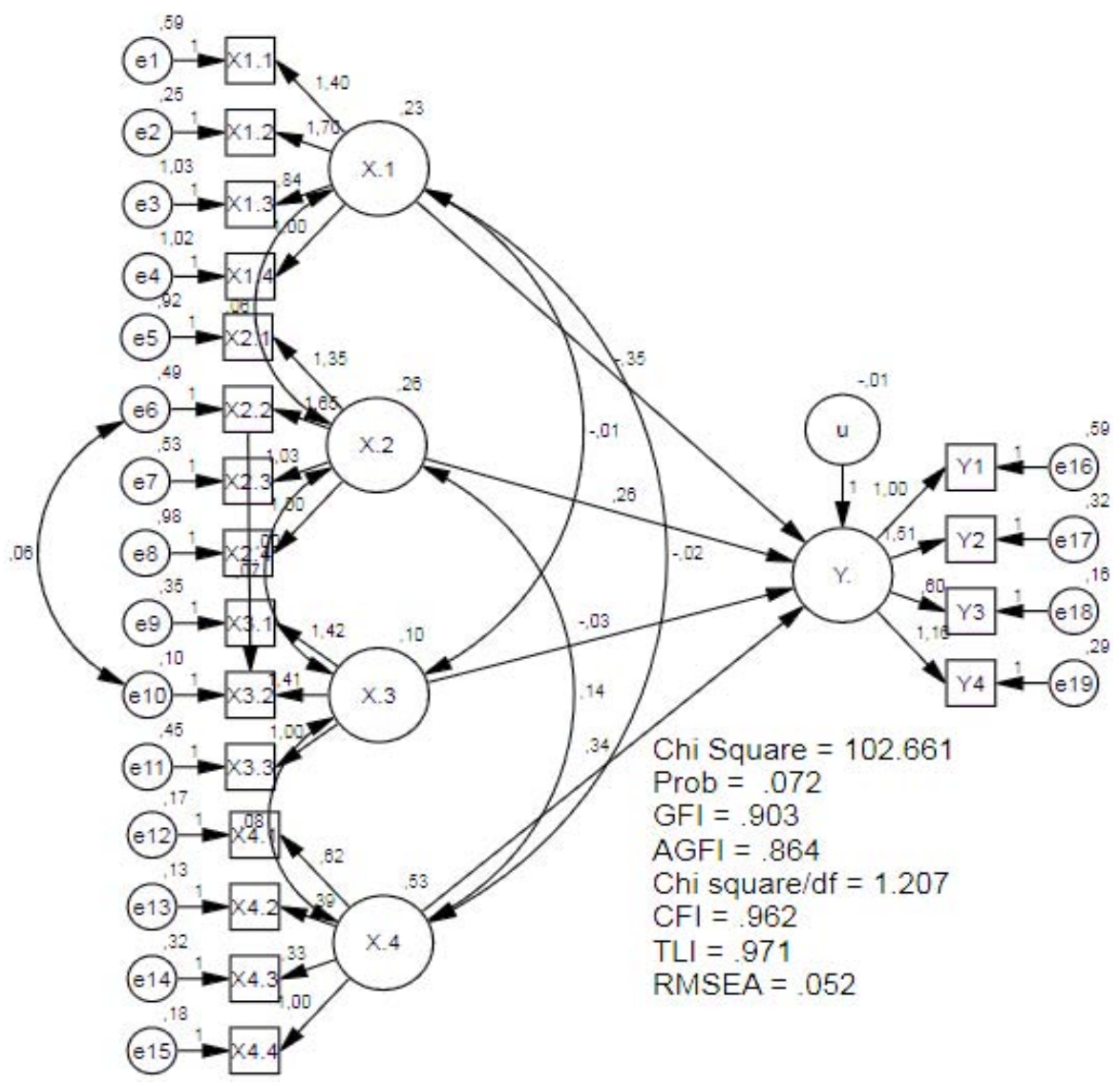

Figure 3. After Modified Model.

The evaluation results of this research can be shown in Table 2 .

Table 2. Goodness of fit Result.

\begin{tabular}{|c|c|c|c|c|c|}
\hline Goodness of Fit Index & Cut off Value & Initial Model & \multirow{2}{*}{ Model Evaluation } & After Modified & \multirow{2}{*}{ Model Evaluation } \\
\hline Chi Square $\left(\chi^{2}\right)$ & Expected to be small & 257,195 & & 102.661 & \\
\hline Probability & $\geq 0.05$ & 0.000 & Marginal & 0.072 & Fit \\
\hline GFI & $\geq 0.90$ & 0.743 & Marginal & 0.903 & Fit \\
\hline AGFI & $\geq 0.90$ & 0.786 & Marginal & 0.864 & Marginal \\
\hline CMIN/DF & $\leq 2.00$ & 2.546 & Marginal & 1.207 & Fit \\
\hline CFI & $\geq 0.95$ & 0.761 & Marginal & 0.962 & Fit \\
\hline TLI & $\geq 0.95$ & 0.856 & Marginal & 0.971 & Fit \\
\hline RMSEA & $\leq 0.08$ & 0.113 & Marginal & 0.052 & Fit \\
\hline
\end{tabular}

Source: Processed primary data, 2016.

Goodness of fit analysis results showed that after being modified all the constructs that are used to form a model of research on the process of confirmatory factor analysis has met the criteria of goodness of fit has been determined. From Table 1 it can be seen that the initial model has a chi-square value / CMIN $(\chi 2)$ with 101 degrees of freedom. The probability of the chi-square was significant $(\mathrm{P}=0.000)$, which means that the marginal model. GFI value obtained for 0.743 . This suggests that the marginal model for the limit on the value of GFI ranges from 0 (poor fit) to 1 (perfect fit). AGFI recommended value is $\geq 0.09$. CMIN / DF or the ratio $\chi 2$ / df initial model was $257.195 / 101=2,546$. This value is higher than the cut of value, so that the model can be said to be around marginal. CFI value on early models of 0.761 indicating that marginal model. TLI value on the model of
0856, indicated that the marginal model. RSMEA value on the initial model is 0.113 which shows that the marginal model.

Model after modified has a chi-square value / CMIN $(\chi 2)$ amounted to 102.661 with 85 degrees of freedom. The probability of the chi-square was significant $(\mathrm{P}=0.072)$, which means that the model fit. GFI value obtained for 0.903, which means that the model fit. AGFI value obtained for 0.864 indicate the marginal value. The recommended value is $\geq 0.09$. CMIN / DF or the ratio $\chi^{2} / \mathrm{df}$ models after being modified is $102.661 / 85=1.207$. These values are qualified, so that the model can be said to be fit. CFI value on the model of 0.962 which indicates that the model fit. TLI value on the model of 0.971 , indicating that the model fit. RMSEA value on the model is 0.052 which showed that the 
model fit. The results of modified model provides a model that is fit despite AGFI value obtained indicates that the marginal model, but still tolerable. The modified model results provide overall model fit better than the initial model.

\subsection{Hypothesis Analysis}

The test of structural model was performed using AMOS (Analysis of Moment Structure) version 18.00. centralization, formalization, interaction, external competition.

Table 3. Regression Weight Structural Equation Models.

\begin{tabular}{|c|c|c|c|c|c|c|}
\hline & & Estimate & S.E. & C.R. & P Label & Description \\
\hline H1 & Centralization $(\mathrm{X} 1) \rightarrow$ Free riding $(\mathrm{Y})$ & -.352 & .215 & -1.638 & .101 & Rejected \\
\hline $\mathrm{H} 2$ & Formalization $(\mathrm{X} 2) \rightarrow$ Free riding $(\mathrm{Y})$ & .243 & .164 & 1.483 & .138 & Rejected \\
\hline H3 & Interaction $(\mathrm{X} 3) \rightarrow$ Free riding $(\mathrm{Y})$ & .607 & .128 & 4.740 & $.000 * *$ & Accepted \\
\hline $\mathrm{H} 4$ & External Competition $(\mathrm{X} 4) \rightarrow$ Free riding $(\mathrm{Y})$ & .329 & .153 & 2.149 & $.032 *$ & Accepted \\
\hline
\end{tabular}

Note: *significant at $0.05 ; * *$ significant at 0.01 .

The relationship between the variables Centralization (X1) with variable free riding $(\mathrm{Y})$ shown by $\mathrm{CR}$ value of -1.612 and $\mathrm{P}$ of 0.107 . While the relationship between the variables Formalization (X2) with variable free riding (Y) shown by $\mathrm{CR}$ values of 1.362 and $\mathrm{P}$-value 0.173 . The relationship between the variables Interaction (X3) and Free riding (Y) shown by $C R$ value of -0.473 and a $P$ value of 0.636 . From the values of $\mathrm{CR}$ can be said to be ineligible significance which is expected $\geq 1.96$ and $\mathrm{P}$-value expected $<0.05$.. It can be concluded that $\mathrm{H} 1 \mathrm{H} 2 \mathrm{H} 3$ rejected. The relationship between external variables competition (X4) with variable Free riding (Y) shown by $\mathrm{CR}$ value of 2.149 . The value of $\mathrm{CR}$ is eligible is $\geq 1.96$, was a $\mathrm{P}$-value of 0.032 which is required to qualify is $<0.05$. With the fulfillment of these two criteria, the hypothesis which states under the external positive effect on free competition riding behavior (H4) is acceptable.

\section{Discussion}

The findings suggest that centralization has no significant effect on free riding behavior. Centralization of franchising networks depends on the distribution of intangible knowledge assets of the franchisor and the franchisee. Intangible assets called specific systems know how and brand name assets have a stronger influence on the allocation of decision rights in the franchise chain. Centralized decisionmaking will be efficient if the decision makers have specific knowledge of the time and place [22], [23]. March and Simon (1958) apply a similar idea to be applied in the design of the organization [24]. Local F\&B franchisee in Indonesia determine to join the franchising business because the franchisor is considered to have a foundation brand recognition, in the sense that the franchisor already has a well established reputation so that customer will trust products sold without seeing the business owner who still lay.

The franchisor offers business systems can provide guarantees of profit, managerial support, and marketing for the franchisee. Additionally franchisor will conduct regular training to employees and franchisees so that the operational standards of quality products and services in accordance with the standards of the franchisor. From some of the points mentioned above, it can be seen that for the franchisee, franchisor is considered to have a business intangible knowledge offered to franchisees so that the franchisee did not mind if the franchisor to centralize. According to Doyle 1990 franchisor's intangible assets is defined as a system of specific know-how and brand assets as capital reputation [25]. Specific systems know how to include: knowledge and skills in business location selection, store's layout arrangement, product development, and procurement [26]. Brand names are defined as invisible asset investments in marketing and promotional systems as a result of asymmetric information between companies and customers [27]. The higher the intangible knowledge assets of the franchisor relative to the franchisee, the higher is the franchisor's portion of residual decision rights, and the more centralized is the franchising network [28]. Sample in this research is the local F\&B franchise that can be said renowned in Indonesia, franchises have a stronger centralization system and the franchisee considers that the centralization of the franchisor did not encourage them to perform free riding behavior.

The nature of formalization in franchising is degree of which the franchisees are provided with rules and procedures that deprive versus encourage creative, autonomous work and learning. High formalization imply explicit rules which are likely to impede the spontaneity and flexibility needed for internal innovation [17]. The study states that the behavior of free riding can not be discounted by the formalization, however, demonstrated that the interaction may prevent free riding behavior. The study states that the free riding behavior cannot be discounted by the formalization, however, the result demonstrated that the interaction may prevent free riding behavior. Since the notion of formalization is what needs to be done, such as written rules and procedures, instruction in packing programs, resource allocation, number of production worker units, employee turnover and dismissal, and so on. This reflects that franchisee in Indonesia prefer informal relationships (interaction informally) as compared to the use of formalization in solving business problems. In a study conducted by Budi Paramita (1992) on 172 companies in several cities in Indonesia also mentions mostly business organizations Indonesia is considered to be less to communicate tasks, generally coordinated through the plan in each adjust or feedback, but not entirely bureaucratic [29].

Formalization measured by manual employee handbooks, organizational structure, written mission statement, manual procedures and rules applied all levels of the organization 
[30]. Local F\&B franchise in Indonesia is not too detailed to formulate things that become the benchmark formalization. However, that does not mean they do not have a set of rules in business. Actually, if observed from the actual events in the field in local Indonesia F\&B franchising, commitment is already formalized by a long-term contract, yet the formal interaction dictated by contract and entrepreneurialfranchisees will always have strategic flexibility.

High formalization can have a negative effect on job satisfaction (Arches, 1991) and can lead to free-riding [31]. However cooperative interaction are found to be useful tools to minimize free riding behavior opportunism. Moreover trust in organizations can have a positive effect on franchise relationship, which means that trust in franchise interactions reduces the need for franchisees oversight through formal (written) contracts [32].

The result indicates that competition (external competition) can also reduce the possibility of free riding behavior in local Indonesia F\&B Franchise. Market competition may put direct pressure on firms to increase quality [33]. The results of this study support previous research conducted by Kidwell et al (2007) which states that external competition can reduce the possibility of free riding behavior [9]. In the local F\&B franchise in Indonesia, both franchisor and franchisee are very observant to read the conditions of external competition. When there are competitors the surrounding environment, they maintain the quality of their services and products so that they can win the competition. In these circumstances, the possibility franchisee to practice free riding can be said to be small. Of the conditions described, it is understood that the local F\&B franchise business in Indonesia, external competition practice minimizes the possibility of free riding.

\section{Conclusion}

The findings suggest that centralization has no significant effect on free riding behavior. This means franchises have a stronger centralization system and the franchisee considers that the centralization of the franchisor did not encourage them to perform free riding behavior. The study states that the free riding behavior cannot be discounted by the formalization, however, the result demonstrated that the interaction may prevent free riding behavior. If observed from the actual events in the field in local Indonesia F\&B franchising, commitment is already formalized by a longterm contract, yet the formal interaction dictated by contract and entrepreneurial-franchisees will always have strategic flexibility. The result indicates that competition (external competition) can also reduce the possibility of free riding behavior in local Indonesia F\&B Franchise. Local F\&B franchise business in Indonesia, external competition practice minimizes the possibility of free riding.

\section{Implication for Future Research}

This study did not examine the relationship between franchisor and franchisee since the franchisee decided to join. The sample in this study was also limited in the local F\&B franchise in Indonesia. In addition, this study did not measure the effect of free riding behavior on the business financial condition. Future research is expected to compare between local F\&B and foreigners F\&B franchise in Indonesia from when the franchisee decided to join the franchisor, but it needs to be considered also to examine the influence of the behavior of free riding on our financial condition and perspectives of consumers to the brand.

\section{References}

[1] C. Helmers and M. Rogers, "Innovation and the survival of new firms in the UK," Rev. Ind. Organ., vol. 36, no. 3, pp. $227-248,2010$.

[2] M. Mendelsohn, The Guide to Franchising, 6th ed. Pennsylvania: Cassell, 1999.

[3] Minesota Department of Employment and Economic Development, An Introduction to Franchising, no. April. 2008.

[4] Lukman Hakim, Info Lengkap Waralaba. Yogyakarta: MedPress, 2008.

[5] A. Karamoy, Sukses Usaha Lewat Waralaba, Jurnalindo. Jakarta, 2009.

[6] S. Muharram, Referensi Teknis Waralaba-Panduan Bagi Usahawan Untuk Merintis Jaringan Waralaba. Jakarta: Pradnya Paramita, 2003.

[7] M. Carney and E. Gedajlovic, "Vertical integration in Franchise systems: Agency theory and resource explanations," Strateg. Manag. J., vol. 12, no. 8, pp. 607-629, 1991.

[8] F. Lafontaine and K. L. Shaw, "Targeting Managerial Control: Evidence From Franchising," Rand J. Econ., vol. 36, no. 1, pp. 131-150, 2005.

[9] R. E. Kidwell, A. Nygaard, and R. Silkoset, "Antecedents and effects of free riding in the franchisor-franchisee relationship," J. Bus. Ventur., vol. 22, no. 4, pp. 522-544, 2007.

[10] J. L. Bradach, "Using the Plural Form in the Management of Restaurant Chains," Adm. Sci. Q., vol. 42, no. 2, pp. 276-303, 1997.

[11] A. I. Rokkan and A. Buvik, "Inter-firm Cooperation and the Problem of Free Riding Behavior: an Empirical Study of Voluntary Retail Chains," J. Purch. Supply Manag., vol. 9, no. 5, pp. 247-256, 2003.

[12] S. C. Michael, "The effect of organizational form on quality: the case of franchising," J. Econ. Behav. Organ., vol. 43, no. 3, pp. 295-318, 2000.

[13] J. Ibrahim and L. Sewu, Hukum Bisnis Dalam Persepsi Manusia Modern. Bandung: Refika Aditama, 2007.

[14] A. Sutedi, Hukum Waralaba, First Edit. Bogor: Ghalia Indonesia, 2008.

[15] W. Gillis and G. J. Castrogiovanni, "The franchising business model: An entrepreneurial growth alternative," Int. Entrep. Manag. J., vol. 8, no. 1, pp. 75-98, 2012. 
[16] O. Ferrell and S. Skinner, "Ethical Behavior and Bureaucratic Structure in Marketing Research Organizations.," J. Mark. Res., vol. 25, no. 1, pp. 103-109, 1988.

[17] C. J. Chen and J. W. Huang, "How organizational climate and structure affect knowledge management-The social interaction perspective," Int. J. Inf. Manage., vol. 27, no. 2, pp. 104-118, 2007.

[18] C. Liao, S. H. Chuang, and P. L. To, "How knowledge management mediates the relationship between environment and organizational structure," J. Bus. Res., vol. 64, no. 7, pp. 728-736, 2011.

[19] M. Schminke, M. L. Ambrose, and R. S. Cropanzano, "The effect of organizational structure on perceptions of procedural fairness.," J. Appl. Psychol., vol. 85, no. 2, pp. 294-304, 2000.

[20] A. Nahm, "The impact of organizational structure on timebased manufacturing and plant performance," J. Oper. Manag., vol. 21, no. 3, pp. 281-306, 2003.

[21] A. H. V. De, "On the Nature, Formation, and Maintenance of Relations Among Organizations.," Acad. Manag. Rev., vol. 1, no. 4, pp. 24-36, 1976.

[22] V. Hayek, Collecticist Economic Planning: Critical Studies on the Possibility of Socialism. London: George Routledge \& Sons Ltd, 1935.

[23] V. Hayek, "Socialist Calculation III: The Competitive Solution. Economica VII (26)," Repr. Hayek, pp. 77-91, 1940.

[24] H. L. Tosi, "James March and Herbert Simon, Organizations," in Theories of Organization, 2008, pp. 93-102.
[25] P. Doyle, "Building successful brands: The strategic options," J. Mark. Manag., vol. 5, no. 1, pp. 77-95, 1989.

[26] M. Kacker, "INTERNATIONAL FLOW OF RETAILING KNOW-HOW-BRIDGING THE TECHNOLOGY GAP IN DISTRIBUTION," J. Retail., vol. 64, no. I, pp. 41-67, 1988.

[27] D. M. Gonzales and B. Lopez, "Market Saturation, Intangible Assets and Monitoring Cost: The Internationalization of Spanish Franchising," 2003.

[28] W. J., "The dual network structure of franchising firms: property rights, resource scarcity and transaction cost explanations," Wind. J, Cliquet G, Hendrikse G, Tuunanen M Econ. Manag. Franch. networks, no. Physica-verlag Heidelberg, pp. 69-88, 2004.

[29] B. Paramita, Masalah Keserasian Budaya dan Manajemen di Indonesia. Jakarta: Lembaga Penerbit Fakultas Ekonomu Universitas Indonesia (LPFEUI), 1992.

[30] D. S. Pugh, D. J. Hickson, C. R. Hinings, and C. Turner, "Dimensions of Organization Structure," Adm. Sci. Q., vol. 13, no. 1, pp. 65-105, 1968.

[31] J. Arches, "Social structure, burnout, and job satisfaction," Soc. Work, vol. 36, no. 3, pp. 202-206, 1991.

[32] C. Ekelund, "Franchisor-Franchisee Relationships: An Interaction Approach," World J. Manag., vol. Vol. 5, no. No. 1, March 2014, pp. 103-109, 2014.

[33] J. Baggs and J.-E. De Bettignies, "Product Market Competition and Agency Cost," J. Ind. Econ., vol. Vol. LV, no. No. 2, June 2007, pp. 0022-1821, 2007. 